\author{
CARCASSES ET VIANDES \\ CARCASSES AND MEAT QUALITY
}

\title{
QUALITÉS DE CARCASSES DES PORCS « LARGE-WHITE » : APTITUDES AUX RATIONNEMENTS SUIVANT LE SEXE ET APRÈS LA CASTRATION
}

\author{
B. DESMOULIN \\ Station de Recherches sur l'Élevage des Porcs, \\ Centre national de Recherches zootechniques, I. N.R. A., \\ 78350 Jouy en Josas

\section{RÉSUMÉ}

Quatre types de porc Large White : le mâle entier et la femelle, le mâle castré et la femelle castrée, ont été soumis de 20 à ıoo $\mathrm{kg}$ à des plans d'alimentation imposés ; soit libéral, soit sévèrement restreint (25 p. IOO).

Les différences d'aptitudes aux rationnements et les différences d'état d'engraissement des carcasses font l'objet d'une série de résultats concernant le sexe, la castration ou le niveau d'alimentation selon un schéma factoriel $2^{3}$.

I. La vitesse de croissance des mâles est supérieure de I 5 p. Ioo à celle des femelles qui présentent une efficacité alimentaire réduite de 9,4 p. Ioo. Entre 20 et Ioo kg., la castration limite de ro p. Ioo la vitesse de croissance et entraîne une dépense alimentaive accrue globalement de 12 p. 100 (soit $38 \mathrm{~kg}$ d'aliment/porc). Les restrictions alimentaires sévères et non progressives, réduisent de $33 \mathrm{p}$. Ioo la vitesse de croissance sans augmenter considérablement les dépenses alimentaires globales. Les mâles entiers sont les plus aptes à subir ces restrictions car ils maintiennent leur indice de consommation et limitent donc la dépense énergétique. La femelle castrée est plus inapte à la restriction que le mâle castré; le bilan déficitaire attribué à la castration représente quantitativement une perte de 20 à 25 p. 100 de la capacité de production.

2. L'état d'engraissement des carcasses est supérieur de io p. ioo chez les femelles que chez les mâles. La castration entraîne une réduction de 30 p. 100 de la qualité des carcasses. La détérioration est ici plus accusée chez les mâles que chez les femelles. Les restrictions alimentaires sévères permettent un reclassement partiel des porcs castrés restreints, jusqu'à un niveau qualitatif sensiblement comparable à celui des carcasses de porcs entiers non restreints.

Les index de densité corporelle varient de I,025- 1,030 à I, 050-I,055 suivant une classification d'état d'engraissement. L'absence de signification du poids des morceaux de découpe est mise en évidence. Par ailleurs, l'épaisseur moyenne du lard dorsal se révèle insuffisante pour déceler les écarts d'adiposité de couverture qui n'excèdent pas $20 \mathrm{p}$. roo. Selon le sexe et après la castra- 
tion, la répartition des graisses de couverture est très différente pour les quatre types de porc Large White; la relation avec l'adiposité des graisses internes est ici discutée.

- Pour la production des viandes porcines, la substitution du mâle castré précocement au mâle entier, dit "verrat " dès $25 \mathrm{~kg}$ de poids vif correspond à une réduction de 50 p. 100 du potentiel de la production quantitative et qualitative du porc d'abattage.

- Les dossiers des anomalies d'odeurs sexuelles des viandes mâles mérite, chez le porc Large White du moins, un examen approfondi des risques de la non-castration. Des études complémentaires doivent être effectuées pour préciser l'influence du sexe et de la castration chez les races porcines différentes du porc Large White.

\section{SUMMARY}

\section{CARCASS QUALITY OF LARGE-WHITE PIGS :}

\section{FEED RESTRICTION ABILITY ACCORDING TO SEX AND AFTER CASTRATION}

Four types of Large White pigs (non-castrated males and females and castrated males and females) were submitted, from 20 ot roo $\mathrm{kg}$, to pre-determined feeding schedules, either $a d$ libitum or severely restricted feeding (25 P. IOO).

Differences in feed restriction abilities of the animals and in fatness of the carcasses depending on sex, castration or feeding level appeared in a series of results according to a factorial scheme 23 .

I. Growth rate of the males exceeded by 15 p. roo that of the females, which showed à 9.4 p. Ioo reduction of feed efficiency. Between 20 and roo $\mathrm{kg}$, castration limited the growth rate by Io $\mathrm{p}$. 100 and gave rise to an increased expenditure of feed $(12 \mathrm{p} .100)$, i. e. $38 \mathrm{~kg}$ feed/pig. Severe and non progressive feed restrictions resulted in a lowering of the growth rate ( $33 \mathrm{p}$. 100) without considerably increasing the total feed expenditure. These feed restrictions were better supported by the non castrated males since they maintained their feed conversion ratio and therefore limited the expenditure of energy. The feed restriction ability was lower in castrated females than in castrated males. The unfavourable effect of castration quantitatively represented a loss of 20 to $25 \mathrm{p}$. 100 of the production capacity.

2. The quality of female carcasses exceeded by io p. Ioo that of the males. Castration caused a reduction of 30 p. 100 of the carcass quality. The deterioration was more marked in males than in females. Owing to severe feed restrictions, castrated pigs could be partially regraded reaching almost similar carcass qualities as those of the non restricted entire pigs.

Specific gravity indexes varied from I 025 -I 030 to I 050 -I 055 according to fatness grading. Difference in weight of the cuts were not significant. In addition, differences lower than $20 \mathrm{p}$. I in the fatness of the subcutaneous layer could not be revealed by the backfat mean thickness. According to sex and after castration, the distribution of subcutaneous fat was very different in the 4 types of Large White pigs; the relationship with internal fatness is discussed.

- The substitution of non castrated males (called boars from $25 \mathrm{~kg}$ live weight) by early castrated males corresponded to a 50 p. 100 reduction of the potential of quantitative and qualitative production of slaughter pigs.

- Anomalies due to bour taint in the meat of males require, at least in Large White pigs, a detailed study of the risks of non castration. Supplementary studies have to be carried out in order to determine the influence of sex and castration in other pig breeds than the Large White. 